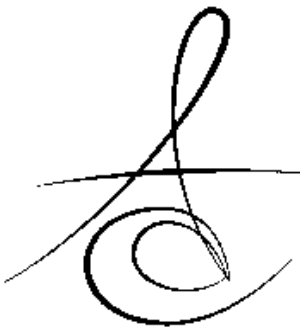

\title{
CUMHURİYET ÜNİVERSİTESİ DİŞ HEKİMLİĞİ FAKÜLTESİ'NE BAŞVURAN HASTALARDA HEPATİT B, C VE HIV GÖRÜLME SIKLIĞI VE FARKINDALIĞIN DEĞERLENDİRİLMESI
}

\section{EVALUATION OF THE PREVELANCE AND AWARENESS OF HEPATITIS B, C AND HIV IN PATIENTS REFERRED TO CUMHURİYET UNIVERSITY FACULTY OF DENTISTRY}

\author{
Yrd.Doç.Dr. Aysun AKPINAR* \\ Yrd.Doç.Dr. Metin ÇALIŞIR* \\ Uzm.Dt. Nebi Cansın KARAKAN* \\ Dr. Suat Serhan ALTINTEPE DOĞAN ${ }^{* *}$ \\ Yrd.Doç.Dr. Ziynet ÇINAR ${ }^{* * *}$
}

Makale Kodu/Article code: 2805

Makale Gönderilme tarihi: 24.04.2016

Kabul Tarihi: 02.11.2016

\section{öz}

Amaç: Çalışmanın amacı Cumhuriyet Üniversitesi Diş Hekimliği Fakültesi'ne başvuran hastalarda Hepatit B, $C$ ve HIV görülme sıklığının yaş, cinsiyet, mesleki eğitim durumu, hastanın daha önce diş tedavisi görüp görmediği, sistemik hastalık varlığı, ailede kronik taşıyıcı birey varlığı, daha önce operasyon geçirip geçirmediği ve aşılı olma durumlarına göre ilişkisinin ve farkındalığın araştırılmasıdır.

Gereç ve Yöntem: Çalışmamızda Cumhuriyet Üniversitesi Diş Hekimliği Fakültesi Periodontoloji Kliniğine başvuran, yaşları 15-75 arasında değişen 622 hasta yer aldı. ELISA yöntemi ile her hastanın taşıyıcılık ve bağışıklık durumu belirlenip, yaş, cinsiyet, mesleki eğitim durumu, daha önce diş tedavisi görüp görmediği, sistemik hastalık varlığı, ailede kronik taşıyıcı birey varlığı, daha önce operasyon geçirip geçirmediği ve aşılı olma durumlarına göre dağılımları tespit edildi.

Bulgular: Çalışmada ailesinde kronik Hepatit B taşıyıcısı bulunan bireylerin taşıyıcılık oranı, ailesinde taşıyıcı bulunmayanlara göre anlamlı olarak daha yüksek bulundu $(p<0.05)$. Diğer parametreler ile taşıyıcılık veya bağışıklık durumu ile ilgili herhangi bir anlamlı ilişki saptanmadı ( $\mathrm{p}>0.05)$.

Sonuç: Çalışmamızda elde edilen bulgulara göre, Hepatit B aşılanma oranlarının arttırılması gerektiği ve bu durumun özellikle ailesinde taşıyıcı bireyler için daha da önem kazandığı sonucuna varıldı.

Anahtar kelimeler: Hepatit B, Hepatit C, HIV, Hepatit B aşısı.

\section{ABSTRACT}

Aim: The aim of this study was to investigate the correlation between Hepatitis B, C and HIV prevelance according to age, gender, education level, previous dental treatment, systemic diseases, family history of chronic porters, previous operation, earlier vaccination and awareness in the patients who have visited Cumhuriyet University Faculty of Dentistry.

Material and Methods: In our study 622 patients ranging from 15-75 years of age took place who applied to Cumhuriyet University Faculty of Dentistry Department of Periodontology. Each patient's carriage and immune status were detected and range according to age, gender, education level, previous dental treatment, systemic diseases, family history of chronic porters, previous operation, earlier vaccination were determined by ELISA method.

Results: It was found that individuals who were chronic Hepatitis B porters in the family also have significantly higher porter ratio $(p<0.05)$. Porter and immune status between other parameters were not found significant ( $p>0.05)$.

Conclusion: According to the results of our study, we concluded that vaccination of Hepatitis $B$ should be increased and this point is important for people who has chronic porters in the family.

Key Words: Hepatitis B, Hepatitis C, HIV, Hepatitis B vaccine

${ }^{*}$ Cumhuriyet Üniversitesi Diş Hekimliği Fakültesi Periodontoloji A.D.

${ }^{*}$ Kocatepe Üniversitesi Diş Hekimliği Fakültesi Periodontoloji A.D.

*** Cumhuriyet Üniversitesi Tıp Fakültesi Biyoistatistik A.D. 


\section{GİRIŞ}

Viral hepatitler günümüzde toplum sağlığı açısından dikkat edilmesi gereken bir konudur. Hepatit B (HBV) ve Hepatit C (HCV) görülme sıklıkları, kronikleşme potansiyelleri, karaciğer sirozu ve hepatosellüler kanser gibi ciddi komplikasyonlara neden olabilmelerinden dolayı önemlidir. Dünya genelinde 400 milyondan fazla bireyin HBV taşıyıcısı olduğu rapor edilmiş olup HBV enfeksiyonu yaklaşık \%5 oranında kronikleşmektedir. HCV, 300 milyondan fazla kişide görülmekte olup kronikleşme oranı \%80'dir. Human immunodeficiency virus (HIV) taşıyıCıSı ise $10-12$ milyondur. ${ }^{1} \mathrm{HBV}, \mathrm{HIV}$ 'den 100 kat daha enfeksiyözdür. Bulaştırıcı en düşük kan miktarı HIV için 0,1 ml iken HBV için 0,00004 ml'dir. Bu verilere bakılarak HBV, HIV kadar önemsenmeyebilir; ancak bu durum özellikle HBV'nin yaygın olduğu ülkemiz açısından daha da önem kazanmaktadır. ${ }^{2,3}$

HBV'nin dağılımı Dünya'daki coğrafi bölgelere göre değişkenlik gösterir ve "düşük", "orta" ve "yüksek" endemik bölgeler olarak 3 grupta incelenir. ${ }^{4}$ Verilere göre ülkemiz "orta endemik bölge" grubuna girmektedir. ${ }^{5}$ HBV enfeksiyonlarının önüne geçmenin en etkili yolu aşılamadır. Ülkemizde ise Dünya Sağlık Örgütünün (WHO) önerileri doğrultusunda 1998 yılından itibaren HBV aşıSı rutin aşılama takviminde yer almaktadır. ${ }^{6}$ HCV daha düşük prevelansa sahip olmakla birlikte hepatit enfeksiyonları içindeki oranı gün geçtikçe artmaktadır. Gelişmiş ülkelerde kronik hepatit taşıyıCısı olan bireylerin \%70 kadarını HCV'li hastalar oluşturmaktadır. ${ }^{7}$ Türkiye'de HCV görülme sıklığı açısından bölgeler arasında önemli bir fark göze çarpmamaktadır. ${ }^{8}$ Son yıllarda ülkemizde kayıtlı HIV pozitif hasta sayısı 7000'e kadar ulaşmıştır. Bunların yaklaşık 1000'i Acquired Immune Deficiency Syndrome (AIDS) hastasıdır. Bununla birlikte kayıtlı olmayan hastaların da mevcut olduğu bilinen bir gerçektir. ${ }^{9}$ Bulaşıcı hastalıkların taşınmasında hastanın sistemik bir hastalığının olması ve geçirilen bir cerrahi operasyon da etkili olabilmektedir. ${ }^{2}$ Ayrıca dental işlemler sırasında HBV başlıca diş hekimliği personeli ve hastalar arasında horizontal olarak, en çok hastadan hekimin yardımcısına ve daha az olarak hekim yardımcısından hastaya bulaşmaktadır. Dikey geçiş ise enfekte dişhekimi veya yardımc personelin HBV enfeksiyonunu perinatal olarak veya diğer kanla geçiş yollarıyla bulaştırmalarıla meydana gelmektedir. ${ }^{19}$ Çalışmamızın amacı diş tedavisi yaptırmak için başvuran hastaların HBV, HCV ve HIV taşıyıcılıklarını çeşitli parametrelere göre değerlendirip, hastalık durumlarının farkında olup olmadıklarını belirlemektir.

\section{GEREÇ VE YÖNTEM}

Çalışmamızda Cumhuriyet Üniversitesi Diş Hekimliği Fakültesi Periodontoloji Kliniği'ne Ocak 2010Nisan 2012 tarihleri arasında başvuran 622 hasta yer aldı. Çalışmada yaş, cinsiyet, mesleki eğitim durumu, daha önce diş tedavisi görüp görmediği, sistemik hastalık varlığı, ailede kronik taşıyıcı birey varlığı, daha önce operasyon geçirip geçirmediği ve aşılı olma durumları her hasta için değerlendirildi. Çalışmamızın verilerine SPSS 18 programı kullanılarak $\mathrm{X}^{2}$ testi uygulandı.

\section{BULGULAR}

Çalışmada yer alan bireylerin yaşları 15-75 arasındadır. Çalışmadaki 622 hastanın 270'i erkek 352'si bayan olmak üzere toplamda HBV taşıyıcısı olan hasta sayısı 15, AntiHBs pozitif hasta sayısı 185, AntiHCV pozitif hasta sayısı ise 8 'dir. AntiHBs pozitif hastaların 79'u daha önce aşı olduğunu belirtmiştir. Aşılanma sonucu antikor oluşmayan birey yoktur. AntiHIV pozitif hasta ise çalışmamızda bulunmamaktadır.

Yapılan analizlere göre ailede kronik HBV taşıyıCısı olan bireylerde de HbsAg (Hepatit B antijeni) pozitif olma durumu ailede pozitif birey olmayanlara göre önemli derecede yüksekti $(p<0.05)$ (Tablo 1$)$. Bunun dışındaki parametrelerde istatistiksel olarak anlamlı bir fark tespit edilmedi ( $p>0.05$ ). Yaş, cinsiyet, meslek ve eğitim durumu, daha önce geçirilen operasyon ve sistemik hastalığa göre kronik taşıyıcılık açısından anlamlı bir fark görülmedi ( $p>0.05$ ) (Tablo 2- 4).

Tablo 1. Ailede HbsAg pozitif birey durumuna göre taşıyıcilık

\begin{tabular}{|l|l|l|l|}
\hline & HbsAg negatif & HbsAg pozitif & Total \\
\hline $\begin{array}{l}\text { Ailede HbsAg olan } \\
\text { bireyler }\end{array}$ & 38 & 5 & 43 \\
\hline $\begin{array}{l}\text { Ailede HbsAg } \\
\text { olmayan bireyler }\end{array}$ & 569 & 10 & 579 \\
\hline Total & 607 & 15 & 622 \\
\hline
\end{tabular}

$X^{2} 0.000 p=0.002 p<0.05$ 
Tablo 2. Eğitim durumu ile HBV taşıyıcılık ilişkisi

\begin{tabular}{|l|l|l|l|}
\hline & HbsAg negatif & HbsAg pozitif & Total \\
\hline Okur-yazar değil & 21 & 0 & 21 \\
\hline İlkokul & 174 & 4 & 178 \\
\hline Ortaokul & 45 & 1 & 6 \\
\hline Lise & 171 & 6 & 177 \\
\hline Lisans ve üstü & 196 & 4 & 200 \\
\hline Total & 607 & 15 & 622 \\
\hline
\end{tabular}

$X^{2} 0.842 p=0.778 p>0.05$

Tablo 3. Daha önceden ameliyat geçirme ile HBV taşıyıcılık ilişkisi

\begin{tabular}{|l|l|l|l|}
\hline & $\begin{array}{l}\text { HbsAg } \\
\text { negatif }\end{array}$ & $\begin{array}{l}\text { HbsAg } \\
\text { pozitif }\end{array}$ & Total \\
\hline Ameliyat geçirmiş & 124 & 5 & 129 \\
\hline $\begin{array}{l}\text { Ameliyat } \\
\text { geçirmemiş }\end{array}$ & 482 & 10 & 492 \\
\hline Total & 606 & 15 & 621 \\
\hline
\end{tabular}

$X^{2} 0.225 p=0.211 p>0.05$

Tablo 4. Sistemik hastalık HBV ilişkisi

\begin{tabular}{|l|l|l|l|}
\hline & $\begin{array}{l}\text { HbsAg } \\
\text { negatif }\end{array}$ & $\begin{array}{l}\text { HbsAg } \\
\text { pozitif }\end{array}$ & Total \\
\hline Sistemik hastalık var & 129 & 6 & 135 \\
\hline $\begin{array}{l}\text { Sistemik hastalık } \\
\text { yok }\end{array}$ & 478 & 9 & 487 \\
\hline Total & 607 & 15 & 622 \\
\hline
\end{tabular}

$X^{2} 0.082 p=0.107 p>0.05$

\section{TARTIŞMA}

Viral hepatitlere yol açan etkenler yaşanılan bölge ve yaşam koşullarına göre farklılık gösterebilmektedir. ${ }^{10}$ Leblebicioğlu ve arkadaşlarının ${ }^{11}$ yaptıkları araştırmada Türkiye'nin batısında HBV prevelansı \%6 iken doğu ve güneydoğu illerinde ise \%12.5-14.3 olarak saptanmışıı. 1995 yılında Poyraz ve arkadaşlarının ${ }^{12}$ Sivas bölgesinde yapmış oldukları bir araştırmada, HBV oranı \%7.5 olarak belirtilmiştir. Özdemir ve arkadaşlarının ${ }^{13}$ yaptıkları çalışmada 15 yaş ve üzerinde olan hastalarda ise bu oran \%5.4 olarak rapor edilmiş ve bu sonuçlarla hastaların daha önce ameliyat geçirmiş olmaları arasındaki ilişki anlamlı bulunmuştur $(p<0.05)$. Çalışmamızda ise daha önce ameliyat geçiren hastalarla HBV bakımından taşıyıcı olma arasında anlamlı bir ilişki tespit edilmedi ( $p>0.05)$. Bu noktada geçmiş yıllarda operasyon öncesinde yeterli önlemlerin alınmamasından kaynaklı bazı eksiklikler yaşanmışken günümüzde bu konuda daha titiz davranıldığı sonucuna ulaşılabilir. Yine de bu konu ile ilgili kesin bir yargıya varmak güçtür. Bununla birlikte bazı akut olgularda "pencere dönemi" olarak adlandırılan dönemde HBsAg ve anti-HBs negatif olarak tespit edilebilmektedir. Bu dönemde anti-HBCIgM testinden pozitif sonuç alınmaktadır. Bu dönemden sonra kanda antiHBs saptanması iyileşmeyi ve oluşan bağışıklı̆ı gösterir. ${ }^{14}$

HBV'nin görülme sıklı̆ına göre dünyadaki bölgeler; prevelansı \%2'den az ise "düşük", \%2-10 arasında ise "orta", \%10'dan fazla ise HBV açısından "yüksek endemik bölge" olarak tanımlanmaktadır. ${ }^{5}$ Ülkemizde ise 1972 yllından itibaren HBV ile ilgili birçok çalışma yapılmıştır. Bu araştırmalardan elde edilen verilere göre, Türkiye'deki HBsAg seroprevelansı ELi̇A yöntemi ile, bölgeden bölgeye değişmekte olup, \%3.9-12.5 arasındadır. Bu verilere göre orta endemik bir bölgede yer aldığımız görülmektedir. Bu nedenle ülkemizde HBV prevelansını düşürebilmek için aşılamanın önemi ortaya çıkmıştır. ${ }^{15} 1998$ yılından itibaren HBV aşısı ülkemizde rutin aşılama takviminde yer alsa da ${ }^{6}$, bizim çalışmamızda yer alan 622 bireyden. yalnızca 73'ü daha önce aşı olduğunu belirtmiştir. Bu da bu konu ile ilgili olarak bireysel farkındalığın gelişmesi gerektiğini göstermektedir.

HCV, HBV'ye benzer özelliklere sahip olmakla birlikte kronikleşme eğilimi daha fazladır. Tüm dünyada kronik olarak enfekte 170 milyondan fazla insanın olduğu rapor edilmiş olup bu sayı oran olarak $\% 2.5^{\prime}$ tir. ${ }^{16} \mathrm{HCV}$ ile yeni enfekte olmuş bireylerin yalnızca \%20-30'unda akut hepatit semptomları görülür. Bulaşma sonrası kronikleşme 45 yaş üzerindekilerin $\% 75-85^{\prime}$ inde, gençlerin ve genç yetişkinlerin ise \%5060 'ında ortaya çıkmaktadır. ${ }^{17}$ Türkiye'deki HCV görülme sıklığı yaklaşık $\% 1.5$ olarak belirtilmiştir. ${ }^{18}$ Çalışmamızda anti-HIV pozitif hasta bulunmaması ise olumludur. Ayrıca daha önce diş tedavisi yaptıran veya cerrahi operasyon geçirmiş bireylerde kronik taşıyıcıllık ile ilgili bir ilişki saptanmaması sevindiricidir. Diş hekimliği bulaşıı hastalıklar ve özellikle viral hepatitler açısından risk grubunda olup, öğrencilikten itibaren düzenli aşılama takvimlerinin oluşturulup bağışıklık tespiti amacıyla antikor titrelerine bakılması önerilmektedir. ${ }^{20}$

Çalışmamızın bulgularına dayanarak ailede HBV taşıyıcısı varsa bireyin de hastalığa yakalanma oranı artmaktadır. Toplumda veya aile içinde bu orandaki

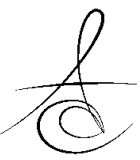


artışın önüne geçilmesindeki en önemli yol ise, bireysel farkındalığın çocukluktan itibaren oluşturulması ve aşı programlarının düzenli olarak uygulanmasıdır.

\section{KAYNAKLAR}

1. Saeed S, Strumpf EC, Walmsley S, How generalizable are the results from trials of Direct Antiviral Agents to people coinfected with HIV/Hepatitis $C$ virus in the real world? Clin Infect Dis 2016; 6: 12-22.

2. Lai $C L$, Ratziu V, Yuen MF, Poynard T. Viral hepatitis B. Lancet 2003;362:2089-94.

3. Akkız H. Hepatit C virüsü infeksiyonu Epidemiyoloji ve korunma. Viral hepatit 2003. 1. Baskı. Ankara: 2002:199-221.

4. Zuckerman JN, Zuckerman AJ. The Epidemiology of Hepatitis B. In: Clinics in Liver Disease Philadelphia: W.B.Saunders; 1999. p. 179-87.

5. Erden $S$, Büyüköztürk $S$, Çalangu $S$, Kardeş BA, Kaysı A. Poliklinik hastalarında $\mathrm{HBsAg}$, antiHBs ve anti-HCV prevelansı. Türk Mikrobiyol Cem Derg 2000; 30: 131-4.

6. Hepatit B Hastalığı Hakknda Genelge. Temel Sağlık Hizmetleri Genel Müdürlüğü. Tarih: 04/06/98 Sayı: 6856.

http://www.saglik.gov.tr/modules.php?name=Cont ent\&pa $=$ showp age\&pid $=67$

7. Ökten A. Hepatit C-giriş. Selim Badur, Kaya Kılıçturgay, Viral Hepatit 2001. Viral İstanbul: Hepatitle Savaşım Derneği; 2001, 180-81.

8. Dursun M, Gül K, Yılmaz Ş, Canoruç F, Ayyıldz O, Değertekin $\mathrm{H}$ : Diyarbakırda kan merkezlerine başvuran gönüllü kan vericilerinin $\mathrm{HBsAg}$ ve $\mathrm{HCV}$ pozitiflik oranları. Akademik Gastroentroloji Dergisi 2003; 3: 130-3.

9. Türkiye Cumhuriyeti Sağlık Bakanlığı Halk Sağlığı Kurumu BulaşıCı Hastalıklar Daire Başkanlığı. HIV/AIDS veri tablosu; 2013.

10. Sakarya S, Tuncer G, Yaşa G, Çiçek C, Kadköylü G, Yükselen $V$. Aydn bölgesindeki kan donörlerinde HBsAg ve anti-HCV prevalansı ve yaş ve cinsiyetle ilişkisi. Klinik Dergisi 2001;14: 22-4.

11. Leblebicioğlu H, Eroğlu C. Acute hepatitis B virus infection in Turkey: Epidemiology and genotype distribution. Clin Microbiol Infect 2004; 10: 537-41.

12. Poyraz Ö, Sümer H, Öztop Y, Saygı G, Sümer Z. Sivas yöresinde genel toplum hepatit $A, B$ ve $C$ virüs belirleyicilerinin araştırılması. Infect Derg 1995; 9: 175-8.

13. Özdemir L, Alim A, Arslan S, Nur N, Kaya S, Demirel $Y$, Özyazıcı G. Sivas ilinde berber ve kuaförlerde HBV, HCV ve HIV seroprevalansı.CÜ Tıp Fakültesi Dergisi 2004; 26: 153-6.

14. Uyanık $M H$, Kuzucu Malçok $H$, Aktaş O. Kan donörlerinde Hepatit $B$, Hepatit $C$ ve HIV-1/2 seroprevelans. AÜTD, 2004; 36: 35-8.

15. Yenen OŞ. Hepatit B. Wilke Topçu A, Söyletir G, Doğanay M. İnfeksiyon Hastalıkları. 1. Baskı. İstanbul: Nobel Tıp Kitabevleri; 1996. p. 664-91.

16. Lavanchy D. The global burden of hepatitis $C$. Liver Int. 2009;29: 74-81.

17. Weinbaum C, Lyerla R, Margolis HS. Prevention and control of infections with hepatitis viruses in correctional settings. Centers for Disease Control and Prevention. MMWR Recomm Rep 2003;52: 136.

18. Barut HŞ, Günal Ö. Dünyada ve Ülkemizde Hepatit C Epidemiyolojisi. Klinik Dergisi 2009; 22: 38-43.

19. Cottone, J.A., Puttaiah, R.: Hepatitis B virüs infection. Current status in dentistry. Dental Clinics of North America, 1996;40: 293- 307.

20. Kömerik N, Akçam Z, Gönen İ, Karaduman Aİ. Diş Hekimliği Fakültesi Öğrencilerinin Hepatit B Aşılanma Durumlarının ve Viral Hepatitler ile İlgili Bilgi Düzeylerinin Araştırıması. Atatürk Üniv. Diş Hek. Fak. 2005;15: 21-25.

\author{
Yazışma Adresi \\ Yrd.Doç.Dr. Aysun AKPINAR \\ Cumhuriyet Üniversitesi \\ Diş Hekimliği Fakültesi \\ Periodontoloji A.D. 58140 Sivas \\ Tel: +903462191010 , \\ Fax:+903462191110, \\ E-MAİL: aysunakpinar73@hotmail.com
}

